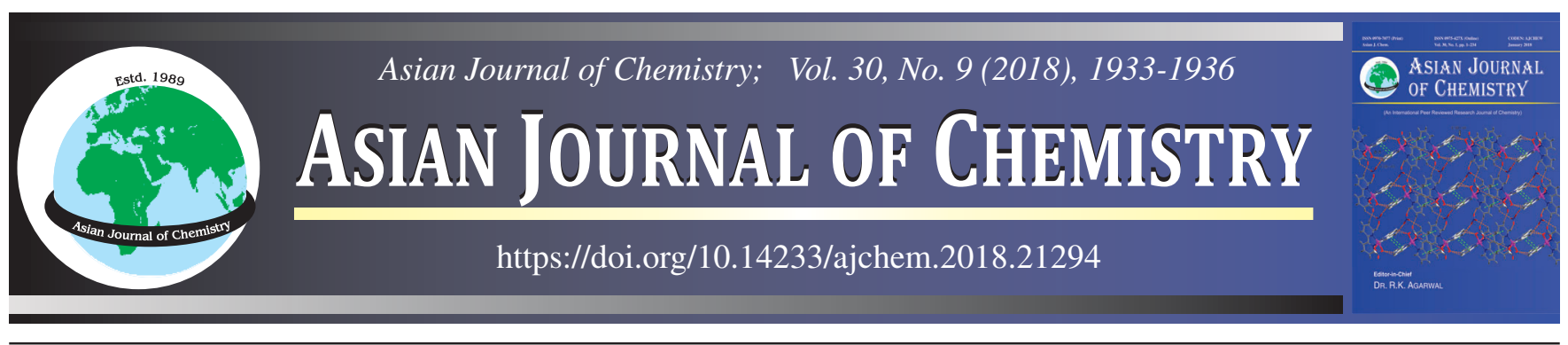

\title{
A Naked-Eye Colorimetric Receptor for Anions Based on Nitro Group Featuring with Benzimidazole Unit
}

\section{R. Rahmawati ${ }^{1,2, *}$, B. Purwono ${ }^{2, *}$ and S. MatsJeh ${ }^{2}$}

${ }^{1}$ Study Program of Chemistry, Department of Education of Mathematics and Natural Sciences, University of Mataram, Jalan Majapahit 62, Mataram, Indonesia

${ }^{2}$ Department of Chemistry, University of Gadjah Mada, Jalan Kaliurang Sekip Utara Bulaksumur 21, Yogyakarta, Indonesia

*Corresponding authors: E-mail: purwono.bambang@ugm.ac.id; tqomari31@gmail.com

Received: 20 February 2018;

Accepted: 24 April 2018;

Published online: 31 July 2018;

AJC-18998

A novel receptor based on nitro group featuring with benzimidazole unit $(\mathbf{S} 2)$ was successfully synthesized and applied to the anion $\left(\mathrm{CN}^{-}, \mathrm{F}^{-}\right.$ and $\mathrm{H}_{2} \mathrm{PO}_{4}^{-}$) recognition. The $\mathbf{S} 2$ changed its colour for light yellow to dark yellow on addition of the anions in DMSO solvent. The LOD and $\mathrm{K}_{\text {ass }}$ values determined by UV-visible titration was $2.8 \times 10^{-6} \mathrm{M}$ and $1.2( \pm 0.25) \times 10^{6} \mathrm{M}^{-1}$ for $\mathrm{CN}^{-}$ion; $1.14 \times 10^{-6} \mathrm{M}$ and $2.5( \pm 0.25)$ $\times 10^{6} \mathrm{M}^{-1}$ for $\mathrm{F}^{-}$ion; and $1.23 \times 10^{-5} \mathrm{M}$ and $6.25( \pm 0.177) \times 10^{6} \mathrm{M}^{-1}$ for $\mathrm{H}_{2} \mathrm{PO}_{4}^{-}$ion, respectively.

Keywords: Colorimetric, Nitro group, Benzimidazole.

\section{INTRODUCTION}

The development of sensors and receptors capable of binding and sensing for anions selectively has received a great attention from chemist due to the key roles played by anions during the chemical, biological and environmental processes [1]. The anion can be recognized either by H-bonding or by the deprotonation of proton in the receptor in organic solvent [2]. Especially, the colorimetric and ratiometric chemosensors appear to be particularly attractive due to their simplicity, high sensitivity and high selectivity. Colorimetric sensing possesses huge advantages in practical application as it can rapidly provide qualitative information about the analyte without any expensive instrument $[3,4]$.

Among the chemosensors for the detections of anions, the colorimetric chemosensor have attracted considerable attention since they provide immediate qualitative signal, which allows direct naked-eye detection of anion because of a specific colour change of solution upon anion complexation [5]. Binding of anions such as $\mathrm{AcO}^{-}, \mathrm{F}^{-}$and $\mathrm{H}_{2} \mathrm{PO}_{4}^{-}$results in a note worthy change in the visible region of spectrum (approximately $100 \mathrm{~nm}$ red shift), which can be detected by the 'naked-eye' [6].

A large numbers of anion receptors containing $\mathrm{NO}_{2}$ subunits have been designed, synthesized and tested for anion recognition and sensing during the past decades [7]. A nitro group functionality was introduced into benzimidazole moieties, which were anticipated to be responsible for colour changes and also to increase hydrogen bond donor tendency. Incorporating the nitro group resulted shifting the wavelength absorbance of sensor, facilitating the occurrence of deprotonation and resulted strong colour of sensor [5].

In the previous study, we designed a chemosensors compound derived from benzimidazole (S1) [8] which are active as flourescence receptor and selectively to detect $\mathrm{CN}^{-}$ion. Sensor $\mathbf{S 1}$ are synthesized from vanillin by keeping $\mathrm{OH}$ group as a binding site. In this project, we design a new chemosensor compound by adding with nitro group at the fifth position on vanillin ring structure, to produce the 5-nitro vanillin. We made a new chemosensor (S2) which are derived from benzimidazole which are bearing by nitro group (Fig. 1).

The nitro group was introduced on $\mathbf{S} 2$ to affects the change of LOD value, $\mathrm{K}_{\text {ass }}$ value and colour mode of the original compound (S1).

\section{EXPERIMENTAL}

Melting point was measured using a Electrothermal-9100, the IR spectra measured using a FTIR Shimadzu Prestige-21, Mass spectra were taken by gas chromatograph-mass spectrometer (Shimadzu-QP2010S), ${ }^{1} \mathrm{H}$ and ${ }^{13} \mathrm{C}$ NMR were measured

This is an open access journal, and articles are distributed under the terms of the Creative Commons Attribution-Non Commercial 4.0 International (CC BY-NC 4.0) License, which allows others to copy and redistribute the material in any medium or format, remix, transform, and build upon the material, as long as appropriate credit is given and the new creations are licensed under the identical terms. 


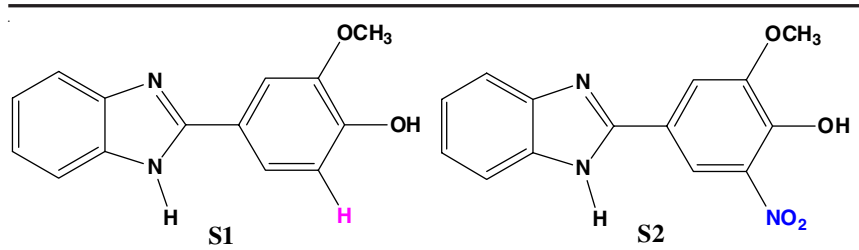

Fig. 1. Structures of $\mathbf{S 1}$ and $\mathbf{S} 2$ compounds

using a JOEL JNM ECA-500 MHz, fluorescent were measured using a Spectro Fluorophotometer Shimadzu RF-6000.

All the reagents obtained commercially were used without further purification: DMSO, DCM, water, ethanol. The material synthesis: vanillin, $o$-phenylendiamine, boric acid. The anion were added in the form of sodium cyanide, sodium flouride and sodium dihydrogen phosphate. All the materials for synthesis is p.a quality Merck.

Method: The method on synthesis of $\mathbf{S 2}$ is applied by Karimi's method [9]. This synthesis used 5-nitrovanillin as a carbonyl sources, using hot water $\left(40^{\circ} \mathrm{C}\right)$ to dillute the reactans and the synthesis was conducted at room temperature. A 5nitrovanillin $(0.32 \mathrm{~g}), o$-phenylendiamine $(0.21 \mathrm{~g})$ and boric acid $(0.1 \mathrm{~g})$, were mixed in $5 \mathrm{~mL}$ of hot water. A mixture was stirred directly at room temperature for $5 \mathrm{~min}$ (the progress of reaction was monitored by TLC). After completion of reaction, the obtained solid was collected by filtration and purified by recrystalization from boiled ethanol (Fig. 2). Colour dark orange powder, $88 \%$ yield, m.p. $207.7-208.5^{\circ} \mathrm{C}$; FTIR $(\mathrm{KBr}$, $v_{\max }, \mathrm{cm}^{-1}$ ): $3441.01 \mathrm{O}-\mathrm{H}$ from phenol dan $\mathrm{N}-\mathrm{H}, 2931.8 \mathrm{C}-\mathrm{H}$ methyl, 2337.72 $\mathrm{C}=\mathrm{N}$ imidazole, $1612.49 \mathrm{C}=\mathrm{C}$ aromatics (3093.82 C-H $\left.s p^{2}\right), 1543.05 \mathrm{NO}_{2}, 1280.73 \mathrm{~cm}^{-1} \mathrm{C}-\mathrm{O}-\mathrm{C}$ ether; ${ }^{1} \mathrm{H}$ NMR (500 Mhz, $\mathrm{CDCl}_{3}$ ): 8.307 (s,1H), 8.021 (s, 1H), 7.764 (d, 1H), $7.554(\mathrm{~m}, 1 \mathrm{H}), 7.074(\mathrm{~s}, 2 \mathrm{H}), 5.573(\mathrm{~s}, 2 \mathrm{H}), 3.869(\mathrm{~s}$, $3 \mathrm{H}) ;{ }^{13} \mathrm{C} \mathrm{NMR}\left(500 \mathrm{MHz}, \mathrm{CDCl}_{3}\right): 56.778,110.991,113.487$, 114.572, 116.856, 119.314, 123.115, 127.588, 137.157, 141.986, 150.02, 151.579; MS (EI) : m/z, $285\left(\mathrm{M}^{+}, 75 \%\right), 122$ $\left(\mathrm{M}^{+}, 100 \%\right)$.

The 5-nitrovanillin compound was synthesized from Vanillin by Yadav method [10] with some modifications. A vanillin $(0.07 \mathrm{~mol})$ was dissolved in $55 \mathrm{~mL}$ of dichloromethane, squirted by $12 \mathrm{~mL}$ of $\mathrm{HNO}_{3}$, then stirred for $20 \mathrm{~min}$ at room temperature, added $25 \mathrm{~mL}$ of ice water then leave it for $2 \mathrm{~h}$, the solid formed was recrystallized with ethanol. The melting point of synthesized product was determined and characterized by FTIR instrument. The synthesized 5-nitrovanillin is light yellow powder, $64 \%$ yield, m.p $175-177^{\circ} \mathrm{C}$ (reference, 176 $\left.{ }^{\circ} \mathrm{C}\right)$; FTIR $\left(\mathrm{KBr}, v_{\max }, \mathrm{cm}^{-1}\right)$ : 1560.77 due to $\mathrm{NO}_{2}$ group.

\section{RESULTS AND DISCUSSION}

The $\mathbf{S 1}$ compound in DMSO solvent shows a colourless solution, absorbed at $\lambda_{\max }=295 \mathrm{~nm}$. Addition of anions to the S1 solution did not any colour change and observation under $366 \mathrm{~nm}$ UV lamp shows a fluorescence response only toward $\mathrm{CN}^{-}$ion (selective). The inclusion of nitro group into $\mathbf{S 2}$ indicated a change in properties and response to anions. The $\mathbf{S 2}$ in DMSO solvent is a yellow colour, its means the $\mathbf{S 2}$ is a colorimetric responsive response and observation under $366 \mathrm{~nm} \mathrm{UV}$ lamp shows non-fluorescence response. The $\mathbf{S 2}$ absorbed at $\lambda_{\max }=450 \mathrm{~nm}$ (visible region), not selective to certains anions because $\mathbf{S} 2$ responds positively to anions. Addition of anions to the $\mathbf{S 2} / \mathrm{DMSO}$ solution causes the colour change along with the increase of anions concentration, from yellow to Amber colour, shifted absorbance wavelength to $\lambda_{\max }=470 \mathrm{~nm}$. Titrations of anions does not change the colour and $\lambda_{\max }$ caused only more strong colour and increase the absorbance value.

Compared with $\mathbf{S 1}$ sensor that are fluorescent and selective against $\mathrm{CN}^{-}$ion with LOD $8.8 \times 10^{-6} \mathrm{M}_{\text {and }} \mathrm{K}_{\text {ass }} 2.5( \pm 0.26)$ $\times 10^{6} \mathrm{M}^{-1}$, the $\mathbf{S 2}$ not only responds as a colorimetric sensor and is not selective towards $\mathrm{CN}^{-}$ion, but also it can detect $\mathrm{F}^{-}$and $\mathrm{H}_{2} \mathrm{PO}_{4}{ }^{-}$ions. With the inclusion of nitro group, the $\mathbf{S 2}$ [LOD value $2.8 \times 10^{-6}$ and $\mathrm{K}_{\text {ass }}$ value $6.25( \pm 0.177) \times 10^{6} \mathrm{M}^{-1}$ ] sensor becomes more sensitive than the $\mathbf{S 1}$.

Naked eye detection of anions: The anion binding study of receptor $\mathbf{S 2}\left(1 \times 10^{-7} \mathbf{M}\right)$ have been investigated by 'nakedeye' in DMSO solution. Visual inspection of receptor $\mathbf{S 2}$ showed a clear colour change from light yellow to dark orange upon addition of $\mathrm{CN}^{-}, \mathrm{F}^{-}$and $\mathrm{H}_{2} \mathrm{PO}_{4}^{-}$ions $\left(1 \times 10^{-4} \mathrm{M}\right)$. On the other hand, addition of $\mathrm{Br}^{-}$and $\mathrm{I}^{-}$into the solution did not result in any colour change (Fig. 3).

UV-visible spectroscopy titration: A solution of $\mathbf{S 2}(1 \times$ $10^{-7} \mathrm{M}$ ) changed from light yellow to dark yellow upon the addition of 40 eq. $\left(2 \times 10^{-5} \mathrm{M}\right)$ of $\mathrm{CN}^{-}$or $\mathrm{F}^{-}$or $\mathrm{H}_{2} \mathrm{PO}_{4}^{-}$. The colouration of the solution was intensified with increasing anion concentration (Fig. 4).

The ability of $\mathbf{S 2}$ to recognize $\mathrm{CN}^{-}, \mathrm{F}^{-}$and $\mathrm{H}_{2} \mathrm{PO}_{4}^{-}$was investigated by monitoring UV-visible spectroscopy. Fig. 5 shows the change in UV-visible spectra of $\mathbf{S 2}$ during titration with anions.

In absence of anion, $\mathbf{S 2}$ absorbed light at $\lambda_{\max }=455 \mathrm{~nm}$ with absorbance value (A) 0.156 . As a concentration of anions $\left(\mathrm{CN}^{-}, \mathrm{F}^{-}\right.$and $\mathrm{H}_{2} \mathrm{PO}_{4}^{-}$) was added, the wavelength shifted to $\lambda_{\max } 470 \mathrm{~nm}$ and absorbance increase. The increasing of anions concentration does not cause any wavelength shifted but just caused increasing of the absorbance (A) intensity.<smiles>COc1cc(C=O)cc([N+](=O)[O-])c1O</smiles>

5-Nitrovanillin (2 mmol)
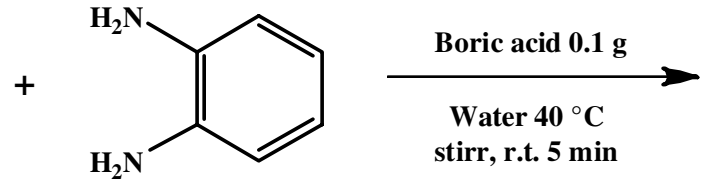

$o$-Phenilendiamine (2 mmol)

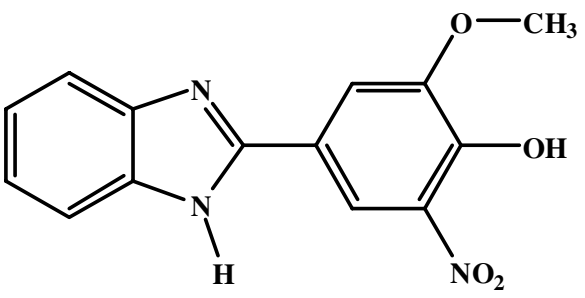

$88 \%$ Dark orange powder (S2)

Fig. 2. Scheme of synthesis the sensor compound (S2) 


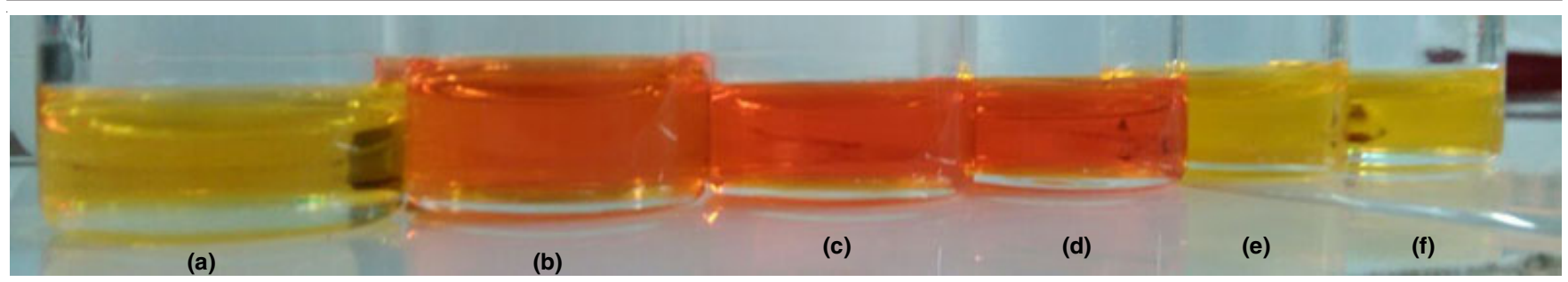

Fig. 3. Visual colour solution (a) $\mathbf{S 2}$, (b) $\mathbf{S} 2+\mathrm{F}^{-}$, (c) $\mathbf{S} 2+\mathrm{CN}^{-}$, (d) $\mathbf{S} 2+\mathrm{H}_{2} \mathrm{PO}_{4}^{-}$, (e) $\mathbf{S} 2+\mathrm{I}^{-}$, (f) $\mathbf{S} 2+\mathrm{Br}^{-}$

(a)

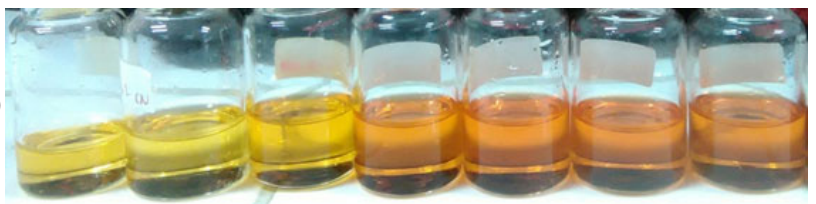

(b)

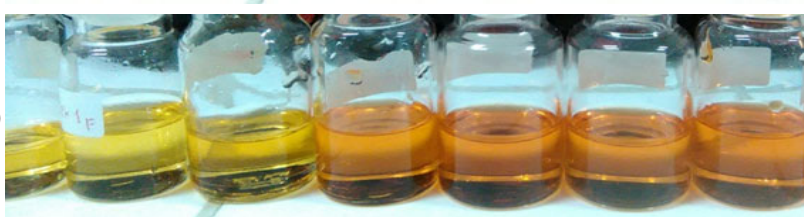

(c)

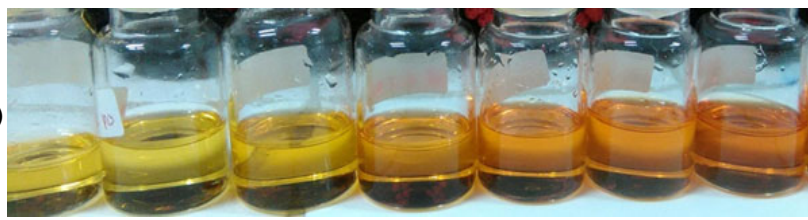

Fig. 4. Colour change of $\mathbf{S 2}$ upon addition increasing concentration of anion : (a) $\mathrm{CN}^{-}$, (b) $\mathrm{F}^{-}$and (c) $\mathrm{H}_{2} \mathrm{PO}_{4}^{-}$

The spectra showed isosbestic point at $\lambda 370 \mathrm{~nm}(\lambda 390$ $\mathrm{nm}), \lambda 375 \mathrm{~nm}$ and $\lambda 380 \mathrm{~nm}$ for $\mathrm{CN}^{-}, \mathrm{F}^{-}, \mathrm{H}_{2} \mathrm{PO}_{4}^{-}$, respectively, indicated that $\mathbf{S} 2$ reacted with ions form ion complex and the hydrogen-bonding [11]. Meanwhile, for $\mathrm{F}^{-}$and $\mathrm{H}_{2} \mathrm{PO}_{4}^{-}$, an isosbestic point was observed during the titration process. Suryanti et al. [12] hypothesized that the anion sensing process first involved hydrogen bonding interaction and than followed by the protonations upon further addition of ions.

In order to determine the stoichiometric ratio between $\mathbf{S 2}$ and anion guest, the method of continuous variation (Job's plot) [7] was used. The $\mathbf{S 2}$-anions $\left(\mathrm{CN}^{-}, \mathrm{F}^{-}\right.$and $\left.\mathrm{H}_{2} \mathrm{PO}_{4}^{-}\right)$complex concentration approaches a maximum when the mole fraction of $\mathbf{S} 2$ is $0.5,0.5,1.0$, respectively. This indicated that $\mathbf{S} 2$ and anions form 1:1, 1:1, 2:1 complexes (stoichiometry ratio), respectively (Fig. 6).
Figs. 7 and 8 show the probability scheme of interaction of $\mathbf{S 2}$-ions complex.

Determination of LOD and $\mathbf{K}_{\text {ass: }}$ : The colorimetric detection limit of $\mathbf{S 2}$ for anions $\left(\mathrm{CN}^{-}, \mathrm{F}^{-}\right.$and $\left.\mathrm{H}_{2} \mathrm{PO}_{4}^{-}\right)$were also calculated by using $\mathrm{UV}^{-v}$ visible data and gave the value of $2.8 \times 10^{-6} \mathrm{M}, 1.14 \times 10^{-5} \mathrm{M}$ and $1.23 \times 10^{-5} \mathrm{M}$, respectively.

On the basis of their stoichiometry ratio, the corresponding binding constant $\left(\mathrm{K}_{\text {ass }}\right)$ of $\mathbf{S 2}$ for anions $\left(\mathrm{CN}^{-}, \mathrm{F}^{-}\right.$and $\left.\mathrm{H}_{2} \mathrm{PO}_{4}^{-}\right)$ were calculated based on the UV-visible titration experiments. For a complex with 1:1 (H:G) stoichiometry ratio, the binding constant could be determined by non-linear fitting analysis of the titration curves according to eqn. 1 and for complex 2:1 $(\mathrm{H}: \mathrm{G})$ the binding constant could be obtained according to the eqn. 2 [6].

$$
\begin{array}{r}
A=A_{o}+\left(A+A_{o}\right) \times \frac{\frac{C H+C G+1}{K}-\left(\frac{C H+C G+1}{K}-4 C H \times C G\right)^{1 / 2}}{2 C H} \\
\left(A-A_{o}\right)=\left[\left(\varepsilon-\varepsilon_{o}\right) \times C H \times K \times C^{2}\right]^{-1}+\left[\left(\varepsilon-\varepsilon_{o}\right) C H\right]^{-1}
\end{array}
$$

The $A$ is intensity of absorbance of host when guest is added; $\mathrm{A}_{\mathrm{o}}$ is intensity of absorbance of host only; $\varepsilon$ is extinction coefficient host-guest; $\varepsilon_{o}$ is extinction coefficient host only; $\mathrm{CH}$ and $\mathrm{CG}$ is concentration of host and guest, respectively; $\mathrm{K}$ is binding constant. The $\mathrm{K}_{\text {ass }}$ result is $1.2( \pm 0.25) \times 10^{6} \mathrm{M}^{-}$ ${ }^{1}$ for $\mathbf{S} 2-\mathrm{CN}^{-}, 2.5( \pm 0.25) \times 10^{6} \mathrm{M}^{-1}$ for $\mathbf{S} 2-\mathrm{F}^{-}$and $6.25( \pm$ $0.177) \times 10^{6} \mathbf{M}^{-1}$ for $\mathbf{S 2}-\mathrm{H}_{2} \mathrm{PO}_{4}^{-}$.

\section{Conclusion}

In summary, we have synthesized a 'naked-eye' colourimetric anion receptor $\mathbf{S 2}$ based on nitro group and its shows colorimetric sensitivity for $\mathrm{CN}^{-}, \mathrm{F}^{-}$and $\mathrm{H}_{2} \mathrm{PO}_{4}^{-}$ions in DMSO solution. The presence of Nitro group resulted in the change of nature and character of the original compound ( $\mathbf{S 1}$ sensor): the fluorescence changed to colourimetric activity, LOD value decreased and $\mathrm{K}_{\text {ass }}$ value increased.
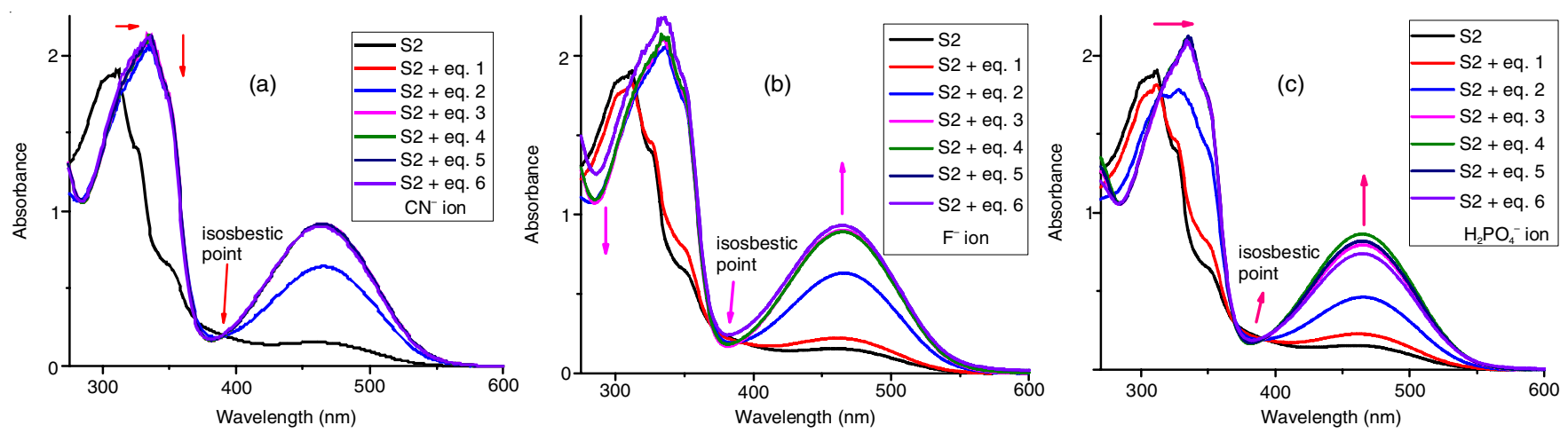

Fig. 5. Change of UV-visible spectral of $\mathbf{S} 2$ upon titration of anion (a) $\mathrm{CN}^{-}$, (b) $\mathrm{F}^{-}$and (c) $\mathrm{H}_{2} \mathrm{PO}_{4}$ 

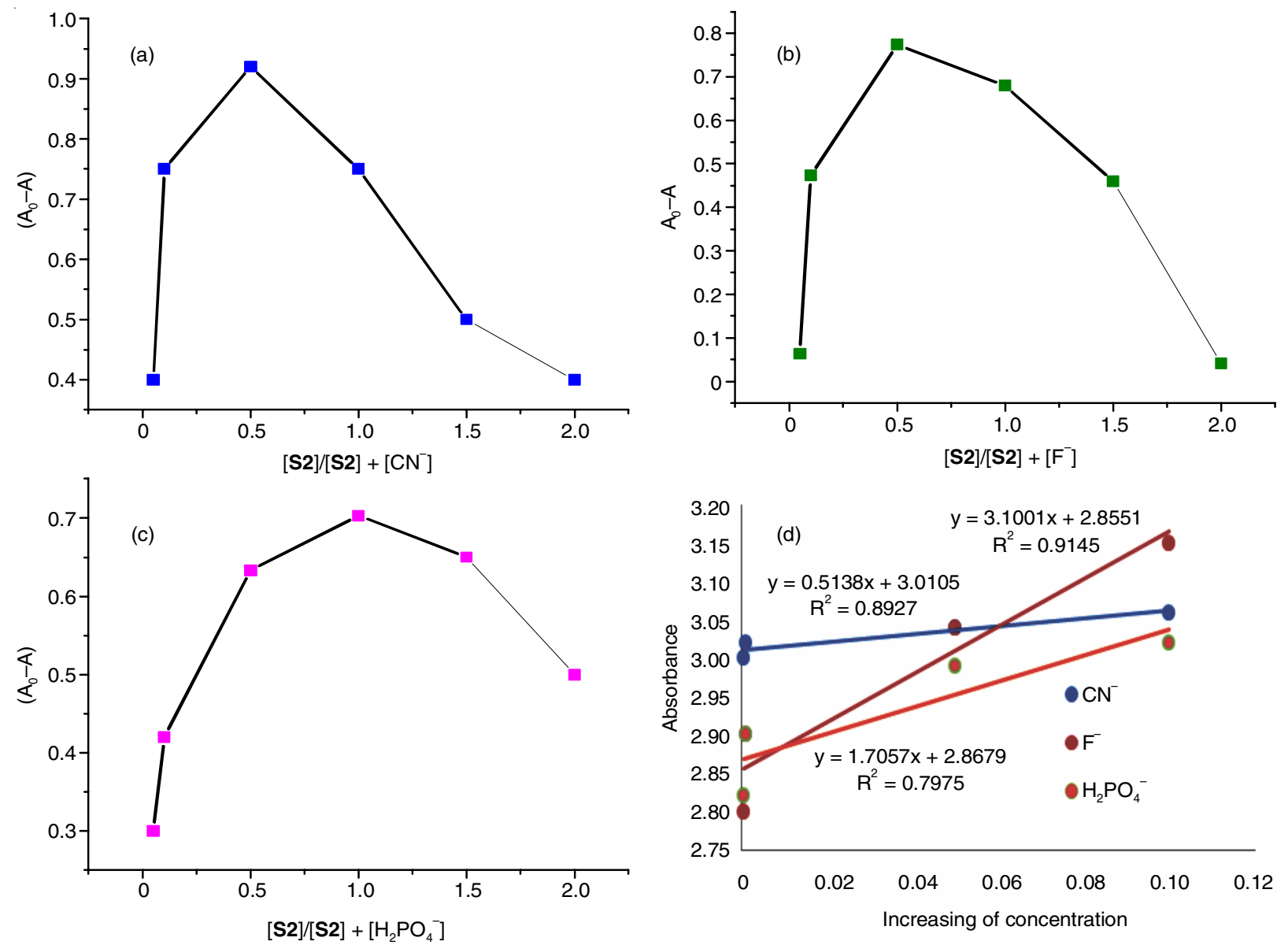

Fig. 6. Job's plot of $\mathbf{S} 2$ ions (a) $\mathrm{CN}^{-}$, (b) $\mathrm{F}^{-}$, (c) $\mathrm{H}_{2} \mathrm{PO}_{4}^{-}$. (d) Linear regression curve of ions

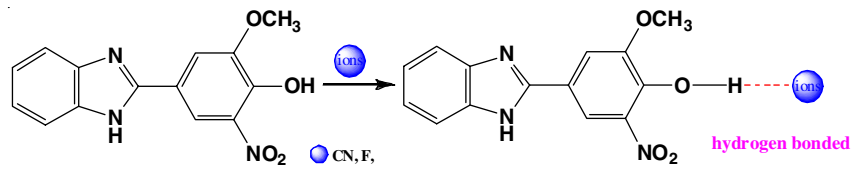

Fig. 7. Scheme of host-guest interaction between S2-ions with 1:1 stoichimetry ratio

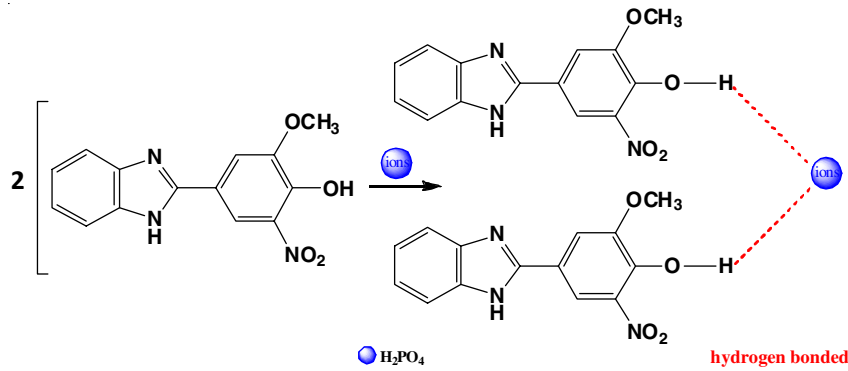

Fig. 8. Scheme of host-guest interaction between S2-ion with 2:1 stoichimetry ratio [Ref. 13]

\section{ACKNOWLEDGEMENTS}

The authors are gratefull for grant from Penelitian Unggulan Perguruan Tinggi (PUPT) Universitas Gadjah Mada with contract number 918/UN-P.III/CT/Dit-Lit/2016; dated March $1^{\text {st }} 2016$.

\section{CONFLICT OF INTEREST}

The authors declare that there is no conflict of interests regarding the publication of this article.

\section{REFERENCES}

1. B. Hu, P. Lu and Y. Wang, Sens. Actuators B Chem., 195, 320 (2014); https://doi.org/10.1016/j.snb.2014.01.058.

2. D. Udhayakumari, S. Velmathi, W.-C. Chen and S.-P. Wu, Sens. Actuators B Chem., 204, 375 (2014);

https://doi.org/10.1016/j.snb.2014.07.109.

3. X. Bao and Y. Zhou, Sens. Actuators B Chem., 147, 434 (2010); https://doi.org/10.1016/j.snb.2010.03.068.

4. R. Jin, W. Sun and S. Tang, Int. J. Mol. Sci., 13, 10986 (2012); https://doi.org/10.3390/ijms130910986.

5. K.S. Moon, N. Singh, G.W. Lee and D.O. Jang, Tetrahedron, 63, 9106 (2007);

https://doi.org/10.1016/j.tet.2007.06.091.

6. J. Shao, H. Lin, M. Yu, Z. Cai and H. Lin, Talanta, 75, 551 (2008); https://doi.org/10.1016/j.talanta.2007.11.048.

7. A. Okudan, S. Erdemir and O. Kocyigit, J. Mol. Struct., 1048, 392 (2013); https://doi.org/10.1016/j.molstruc.2013.04.077.

8. R. Rahmawati, B. Purwono and S. Matsjeh, Asian J. Chem., 29, 1959 (2017); https://doi.org/10.14233/ajchem.2017.20662.

9. Z. Karimi-Jaberi and M. Amiri, E-J. Chem., 9, 167 (2012); https://doi.org/10.1155/2012/793978.

10. U. Yadav, H. Mande and P. Ghalsasi, J. Chem. Educ., 89, 268 (2012); https://doi.org/10.1021/ed100957v.

11. S. Ghosh, M.A. Alam, A. Ganguly and N. Guchhait, Spectrochim. Acta A, 149, 869 (2015); https://doi.org/10.1016/j.saa.2015.04.025.

12. V. Suryanti, M. Bhadbhade, H.M. Chawla, E. Howe, P. Thordarson, D.S. Black and N. Kumar, Spectrochim. Acta A, 121, 662 (2014); https://doi.org/10.1016/j.saa.2013.11.108.

13. N.A. Hamedan, S. Hasan, H.M. Zaki and N.Z. Alias, IOP Conf. Series: Mater. Sci. Eng., 172, 012038 (2017); https://doi.org/10.1088/1757-899X/172/1/012038. 